\title{
Formulation and antibacterial activity test toothpaste combination of triclosan-extract ethanol of suji leaves (Pleomele angustifolia N.E Brown)
}

\section{Formulasi dan uji aktivitas antibakteri pasta gigi kombinasi triklosan- ekstrak etanol daun suji (Pleomele angustifolia N.E Brown)}

\author{
Elya Zulfa*, Rima Andriani \\ Departemen Farmasetika dan Teknologi Farmasi, Fakultas Farmasi \\ Universitas Wahid Hasyim Semarang \\ Jl. Menoreh Tengah X/22 Sampangan Semarang 50236
}

Accepted: 11-10-2017

\begin{abstract}
ABSTRAK
Pada umumnya, di masyarakat daun suji digunakan sebagai obat kumur untuk menghilangkan plak. Pasta gigi merupakan salah satu bentuk sediaan yang cocok untuk kesehatan mulut dengan bahan aktif triklosan, namun triklosan bersifat korosif, resisten terhadap bakteri, dan menurunkan sistem hormonal, khususnya hormon tiroid. Penelitian ini bertujuan untuk mengetahui pengaruh penambahan variasi konsentrasi kombinasi triklosan-ekstrak etanol daun suji (T-EEDS) pada sediaan pasta gigi terhadap karakteristik fisika kimia, dan aktivitas antibakteri pada Streptococcus mutans. Ekstrak daun suji diperoleh dengan maserasi menggunakan etanol 70\%, kemudian dilakukan pembuatan sediaan pasta gigi dengan variasi kombinasi T-EEDS yaitu FI (1:0), FII $(0,5 ; 0,5)$, FIII (0:1). Pasta gigi yang dihasilkan diuji karakteristik fisika kimia (organoleptik, viskositas, $\mathrm{pH}$, dan daya busa), dan aktivitas antibakteri. Hasil pengujian dianalisis secara deskriptif. Berdasarkan hasil penelitian yang diperoleh maka dapat disimpulkan bahwa hasil pengujian karakteristik fisika kimia menunjukkan hasil bahwa semua formula pasta gigi memenuhi karakteristik fisik kimia pasta gigi. Pasta gigi T-EEDS $(0,5: 0,5)$ (FII) memiliki aktivitas antibakteri yang kuat terhadap Streptococcus mutans sehingga dapat digunakan sebagai alternatif pengganti sediaan yang sudah ada dipasaran dengan zat aktif triklosan.
\end{abstract}

Kata kunci: daun suji, triklosan, pasta gigi, aktivitas antibakteri

\begin{abstract}
The suji leaf are generally used by the community as a gargle to remove plaque. Toothpaste is one form of dosage suitable for oral health with triclosan active ingredients, but triklosan is corrosive, resistant to bacteria, and decrease the hormonal system, especially the thyroid hormone. The aim of this research is to know the effect of the addition of variation of the concentration of combination of triclosan-ethanol extracts of suji leaf (T-EESL) on toothpaste preparation to the chemical characteristics, antibacterial activity of Streptococcus mutans. The ethanol extract of $70 \%$ of suji leaf was obtained by maceration method, then made toothpaste preparation with variation of T-EESL combination of FI (1:0), FII (0,5:0,5), FIII (0:1).
\end{abstract}


Toothpaste was tested chemical physics characteristics (organoleptic, viscosity, $\mathrm{pH}$, and foam power), antibacterial activity test. The test results are analyzed descriptively. Based on the results of the research obtained it can be concluded that the results of testing the physical physics of chemistry showed the results that all toothpaste formulas meet the physical characteristics of chemical toothpaste. T-EESL toothpaste $(0.5: 0,5)$ (FII) has strong antibacterial activity against Streptococcus mutans so it can be used as an alternative to the existing dosage preparation in the market with triclosan active substance.

Keywords: suji leave, triclosan, tooth paste, antibacterial activity

\section{PENDAHULUAN}

Gigi merupakan suatu bagian yang paling penting di dalam rongga mulut. Masalah kesehatan mulut yang paling sering dialami adalah kejadian radang gusi yang mana disebabkan karena terabaikannya kebersihan gigi dan mulut, sehingga terjadilah plak (Anitasari and Rahayu, 2005).

Sediaan pasta gigi merupakan suatu sediaan semi padat yang terdiri dari bahan penggosok, pembersih, dan bahan tambahan lain yang bertujuan agar zat aktif dapat bekerja pada permukaan gigi, melindungi dari kerusakan yang disebabkan oleh bakteri mulut seperti Streptococcus mutans. Zat aktif yang umum digunakan untuk sediaan pasta gigi adalah triklosan (Mitsui, 1998). Pasta gigi komersial yang biasanya beredar di pasaran banyak menggunakan triklosan $0,3 \%$ sebagai antiplak, namun produk Over The Counter (OTC) yang mengandung triklosan sebagai antibakteri bersifat korosif, pada beberapa studi menunjukkan adanya resiko mengalami resistensi bakteri, dan berpengaruh terhadap penurunan sistem hormonal khususnya hormon tiroid (FDA, 2016).

Adanya isu back to nature sekarang ini, memunculkan ide pengembangan pasta gigi yang berbahan aktif herbal salah satunya adalah daun suji (Pleomele angustifolia N.E Brown). Suji merupakan suatu tanaman perdu tegak atau pohon kecil dengan tinggi $6-8 \mathrm{~cm}$. Pada masyarakat, daun suji umumnya digunakan sebagai pewarna alami pada makanan karena selain memberi warna yang khas, juga memiliki aroma yang harum. Berdasarkan penelitian Putri et al., (2012) menyatakan bahwa warna yang khas tersebut berasal dari kandungan klorofil pada daun suji. Pada masyarakat, pemanfaatan daun suji untuk kesehatan mulut hanya sebatas pada penggunaan sebagai obat kumur penghilang plak gigi saja. Penelitian Andharini (2012) menyatakan bahwa ekstrak etanol daun suji memiliki kandungan polifenol, flavonoid, dan saponin yang terbukti memiliki khasiat sebagai antibakteri pada staphylococcus aureus dan shigella sp, dimana aktivitas tertinggi terlihat pada ekstrak etanol daun suji konsentrasi 25\%. Sedangkan penelitian Faridah, et al., (2014) menunjukkan hasil bahwa ekstrak etanol daun suji memiliki aktivitas antibakteri pada Mycobacterium Tuberculosis pada konsentrasi $8 \mathrm{mg}$ dan S. pneumonia pada konsentrasi $4 \mathrm{mg}$. Kandungan klorofil pada daun suji juga terbukti memiliki aktivitas antioksidan secara in vitro melalui penghambatan 2,2-diphenyl-1picrylhidrazyl (DPPH) (Jokopriyambodo, et al., 2014) dan aktivitas antioksidan secara in vivo dengan menurunkan kadar malondealdehid dan meningkatan kadar enzim superoxide dismutase (SOD) dan katalase pada tikus spraguey dowley (Pragdimurti, et al., 2006).

Berdasarkan latar belakang di atas, maka penelitian ini bertujuan untuk melihat pengaruh variasi konsentrasi T-EEDS pada sediaan pasta gigi terhadap karakteristik fisika kimia sediaan, aktivitas antibakteri.

\section{METODE PENELITIAN \\ Alat dan Bahan}

Alat-alat yang digunakan yaitu peralatan gelas standar (Iwaki Pyrex), toples, mortir dan stamper, timbangan digital analitik (Ohaus), timbangan simplisia (Henherr), pH-meter (Hanna), blender (Philips), vacuum rotary evaporator (Heidolph) Viskometer (Rion), autoklaf (All American), Ose, LAF (Airtech), bejana anaerob (Scientific), incubator (Binder), dan jangka sorong (Vernier caliper $150 \times 0,05 \mathrm{~mm}$ ). Bahan uji yang digunakan adalah daun suji dengan spesifikasi daun tidak terlalu muda berasal dari Desa Paninggaran Kabupaten Pekalongan. Bahan kimia yang digunakan 
adalah etanol 70\% (MERCK), Ttriklosan (MERCK), Kalsium Karbonat Light (MERCK), Natrium Lauril Sulfat (MERCK), Gliserin (SIGMA ALDRICH), CMC Na (MERCK), Karbomer (MERCK), Sakarin Na, Oleum Mentha Piperita, Metil Paraben, Aquadestilata, Bakteri Streptococcus mutans, larutan $\mathrm{NaCl}$ 0,9\%, larutan standard Mc. Farland, anaerobic kit, media agar darah, media BHI (Merck), dan media MHA (Merck).

\section{Jalannya Penelitian \\ Determinasi tanaman}

Tanaman suji dideterminasi di Laboratorium Biologi MIPA UNDIP Semarang.

\section{Pengumpulan bahan, sortasi, dan proses penyerbukan}

Daun suji diperoleh dengan cara memetik langsung daun yang berwarna hijau tua. Daun suji yang sudah dikumpulkan dilakukan sortasi untuk dipisahkan dari kotoran-kotoran kemudian di cuci dengan air yang mengalir. Daun suji yang telah bersih dipotong-potong, kemudian dilanjutkan dengan proses pengeringan menggunakan oven pada suhu $50^{\circ} \mathrm{C}$. Proses pembuatan serbuk simplisia dilakukan dengan Blender hingga halus dan diayak. Serbuk yang diperoleh kemudian disimpan dalam wadah tertutup rapat hingga dilakukan proses ekstraksi.

\section{Pembuatan ekstrak etanol daun suji}

Pembuatan ekstrak dilakukan dengan metode maserasi menggunakan etanol $70 \%$ dengan perbandingan 1:10. Tahap pertama Serbuk sebanyak $2 \mathrm{~kg}$ direndam dengan etanol sebanyak $14 \mathrm{~L}$ dalam wadah tertutup, diamkan selama 3 hari dan diaduk sesering mungkin. Setelah 3 hari disaring, ampas dimaserasi kembali dengan etanol sebanyak $6 \mathrm{~L}$ dalam wadah tertutup, diamkan selama 3 hari dan diaduk sesering mungkin, setelah itu disaring. Semua filtrat yang dihasilkan diuapkan dengan vacum rotary evaporator pada suhu $50{ }^{\circ} \mathrm{C}$ hingga didapat ektrak kental. Ekstrak kental yang diperoleh dihitung rendemennya dengan persamaan (1).

$$
\text { Rendemen }=\frac{\text { Bobot ekstrak kental }}{\text { Bobot serbuk simplisia }} \times 100 \%
$$

\section{Pembuatan sediaan pasta gigi dari 3 formula}

Formula pembuatan pasta gigi dari 3 formula dapat dilihat pada Tabel I.

Tabel I. Formula pasta gigi variasi konsentrasi T-EEDS dengan bahan pengikat CMCNa

\begin{tabular}{lcccc}
\hline \multicolumn{1}{c}{ Bahan } & \multicolumn{4}{c}{ Kadar $(\%) \mathbf{b} / \mathbf{b}$} \\
\cline { 2 - 5 } & F1 & FII & FIII & K (-) \\
\hline Triklosan & 0,3 & 0,15 & 0 & 0 \\
EEDS & 0 & 0,15 & 0,3 & 0 \\
Kalsium karbonat & 47 & 47 & 47 & 47 \\
Natrium lauril sulfat & 2 & 2 & 2 & 2 \\
Gliserin & 27 & 27 & 27 & 27 \\
CMC Na & 5,5 & 5,5 & 5,5 & 5,5 \\
Karbomer & 0,5 & 0,5 & 0,5 & 0,5 \\
Saccharin sodium & 0,2 & 0,2 & 0,2 & 0,2 \\
Oleum mentha & 0,1 & 0,1 & 0,1 & 0,1 \\
Metil paraben & 0,18 & 0,18 & 0,18 & 0,18 \\
Akuades sampai & 100 & 100 & 100 & 100 \\
\hline
\end{tabular}

Pembuatan pasta gigi dimulai dengan $\mathrm{CMC} \mathrm{Na}$ dan Karbomer ditimbang, dikembangkan dengan akuades, Kalsium karbonat light ditimbang, ditambahkan sedikit-sedikit ke dalam pengikat sambil diaduk hingga rata kemudian ditambahkan gliserin diaduk sampai homogen. Sakarin Na, natrium lauril sulfat, dan metil paraben masing-masing dilarutkan dalam Akuades kemudian 
dicampurkan sampai homogen. Ekstrak etanol daun suji ditimbang dilarutkan dalam Etanol 70\% kemudian diencerkan dengan Akuades dimasukkan bersama dengan triklosan dalam campuran diaduk sampai homogen. Oleum Menthae Piperitae ditimbang, masukan dalam campuran, diaduk sampai homogen. Sisa Aquades ditambahkan, diaduk dengan stamper sampai terbentuk pasta. Sediaan yang telah jadi dimasukkan kedalam tube yang terlindung cahaya.

\section{Uji Karakteristik fisika kimia sediaan pasta gigi T-EEDS}

Uji organoleptis dilakukan dengan cara mengamati tekstur, bau, rasa, dan homogenitas; Uji viskositas dilakukan dengan mengambil 100 gr pasta gigi, kemudian diukur dengan alat Viskometer.; Uji pH dilakukan dengan mengambil 2 gram pasta gigi, kemudian diukur dengan $\mathrm{pH}$-meter; dan uji daya busa dilakukan dengan mengambil $500 \mathrm{mg}$ sampel dan letakkan di atas sikat gigi, kemudian masukkah dalam tabung yang telah ditambah sedikit air, lalu digojog. Buih yang terbentuk diukur berapa ketinggiannya.

\section{Uji aktivitas antibakteri pasta gigi T-EEDS}

Uji aktivitas antibakteri menggunakan teknik sumuran (Lay, 1994). Pertama-tama, alat-alat gelas dan alat-alat non gelas disterilkan terlebih dahulu di dalam autoklaf pada suhu $121^{\circ} \mathrm{C}$ selama 2 jam. Jarum ose dibakar dengan api bunsen.

\section{Pembuatan standar kekeruhan larutan (Larutan Mc. Farland)}

Campurkan antara larutan asam sulfat 0,36 N Sebanyak 99,5 mL dengan larutan $\mathrm{BaCl}_{2} \cdot 2 \mathrm{H}_{2} \mathrm{O}$ sebanyak 0,5 $\mathrm{mL}$ dalam Erlenmeyer, campuran dikocok sampai keruh. Kekeruhan ini dipakai sebagai standar kekeruhan suspensi bakteri uji.

\section{Pembuatan suspensi bakteri uji}

Bakteri uji pada media agar miring diambil dengan menggunakan kawat ose steril lalu disuspensikan ke dalam tabung yang berisi $2 \mathrm{~mL}$ larutan $\mathrm{NaCl}$ 0,9\% sampai diperoleh kekeruhan yang sama dengan standar kekeruhan larutan Mc. Farland.

\section{Peremajaan bakteri uji}

Peremajaan bakteri bertujuan untuk meremajakan kembali bakteri dari bakteri indukan agar miring ke dalam larutan NB (Nutrien Broth). Kultur bakteri uji yang akan digunakan disiapkan dengan cara mengambil satu ose bakteri dari agar miring NA, kemudian diinokulasikan ke dalam $10 \mathrm{~mL}$ NB steril. Setelah itu diinkubasi pada suhu $37{ }^{\circ} \mathrm{C}$ selama 24 jam. Diperoleh inokulum yang langsung dapat digunakan untuk pengujian aktivitas antibakteri.

\section{Pengujian aktivitas antibakteri pasta gigi kombinasi T-EEDS dengan Metode Sumuran}

Metode sumuran didasarkan pada kemampuan senyawa-senyawa antibakteri yang diuji untuk menghasilkan jari-jari zona penghambatan di sekeliling sumur uji terhadap bakteri yang digunakan sebagai penguji. Pengujian aktivitas antibakteri dimulai dengan menyiapkan media pertumbuhan bakteri. Pembuatan media dilakukan dengan cara mencampurkan Nutrien Agar 4,2 gram dengan akuades $210 \mathrm{~mL}$ dalam erlenmeyer, kemudian dilakukan pengadukan sambil dipanaskan menggunakan kompor listrik hingga larutan media homogen yang ditandai oleh warna larutan yang jernih, selanjutnya erlenmeyer ditutup dengan kapas dan disterilisasi pada suhu $121{ }^{\circ} \mathrm{C}$ selama 15 menit. Setelah sterilisasi, media didinginkan dalam keadaan tertutup pada LAF sampai suhu kurang lebih mencapai $40{ }^{\circ} \mathrm{C}$ lalu suspensi bakteri uji diinokulasikan ke dalam erlenmeyer dan setelah homogen didistribusikan ke dalam cawan petri. Media yang telah diinokulasi kultur bakteri uji tersebut dibiarkan hingga membeku. Media yang sudah diinokulasi dibuat empat sumuran, kemudian dimasukkan pasta gigi berbagai formula masing-masing sebanyak $100 \mathrm{mg}$, media diinkubasi pada suhu $37{ }^{\circ} \mathrm{C}$ selama 48 jam. 


\section{Penghitungan zona penghambatan}

Zona penghambatan senyawa antibakteri diukur berdasarkan jari-jari penghambatan berupa area bening di sekeliling sumuran. Pengukuran jari-jari dilakukan dengan mengukur jarak dari tepi sumur uji ke batas lingkaran zona hambat menggunakan jangka sorong (ketelitian 0,05 mm) pada beberapa sisi sumur uji, lalu cari nilai rata-ratanya.

\section{Analisis Data}

Data yang diperoleh dari pengujian dianalisis secara deskriptif.

\section{HASIL DAN PEMBAHASAN}

Hasil penelitian menunjukkan bahwa rendemen ekstrak yang diperoleh sebesar 23,62\%. Identifikasi senyawa aktif menunjukkan hasil bahwa ekstrak etanolik daun suji mengandung senyawa alkaloid, flavonoid, saponin, dan tannin (Tabel II).

Tabel II. Kandungan senyawa aktif ekstrak daun suji

\begin{tabular}{cccc}
\hline $\begin{array}{c}\text { Kandungan } \\
\text { Kimia }\end{array}$ & Pereaksi & Pengamatan & Keterangan \\
\hline Alkaloid & Dragendrof & terbentuk endapan jingga & + \\
Flavonoid & $\mathrm{Mg} \mathrm{dan} \mathrm{HCl}$ & terbentuk warna jingga & + \\
Saponin & Digojok & terbentuknya busa secara stabil & + \\
Tannin & $\mathrm{FeCl}_{3} 1 \%$ & terbentuk warna hijau kehitaman & + \\
\hline
\end{tabular}

\section{Karakteristik fisika kimia pasta gigi daun suji} Organoleptik

Tabel III. Hasil organoleptik pasta gigi ekstrak etanolik daun suji

\begin{tabular}{llccc}
\hline Parameter & \multicolumn{1}{c}{ Warna } & \multicolumn{1}{c}{ Bentuk } & Aroma & Homogenitas \\
\hline \multicolumn{1}{c}{ FI } & Putih & Semi padat & Khas daun suji mint & Homogen \\
FII & Putih agak kehijauan & Semi padat & Khas daun suji mint & Homogen \\
FIII & Putih agak kehijauan & Semi padat & Khas daun suji mint & Homogen \\
K(-) & Putih & Semi padat & Mint & Homogen \\
\hline Keterangan & : & & \\
FI & : Pasta gigi T-EEDS (1,0:0,0) & & \\
FII & : Pasta gigi T-EEDS (0,5:0,5) & & \\
FIII & : Pasta gigi T-EEDS (0,0:1,0) & & \\
K(-) & : Pasta gigi tanpa T-EEDS & &
\end{tabular}

Hasil uji organoleptik menunjukkan bahwa formulasi basis pasta gigi T-EEDS berbagai formula memiliki tekstur yang semi padat, putih agak kehijauan, dan bau yang khas daun suji kombinasi mint, serta homogen.

\section{PH}

Uji $\mathrm{pH}$ dilakukan dengan menggunakan alat $\mathrm{pH}$ meter khusus sediaan semi padat.Uji $\mathrm{pH}$ pada pasta gigi dilakukan bertujuan untuk mengetahui tingkat keasam-basaan sediaan pasta gigi Hasil uji $\mathrm{pH}$ dapat dilihat pada Tabel IV. 
Tabel IV. Hasil pengukuran pH pasta gigi T-EEDS dengan berbagai formula

\begin{tabular}{cc}
\hline Formula & Rata-rata \pm SD \\
\hline FI & $7,59 \pm 0,51$ \\
FII & $7,07 \pm 0,23$ \\
FIII & $7,24 \pm 0,01$ \\
K(-) & $7,23 \pm 0,03$ \\
\hline
\end{tabular}

Hasil uji $\mathrm{pH}$ formula sediaan pasta gigi T-EEDS menghasilkan $\mathrm{pH}$ antara 7,07-7,59 yang masih berada dalam kisaran $\mathrm{pH}$ mulut normal yaitu 4,5-10,5 sehingga sediaan pasta gigi ini aman untuk digunakan.

\section{Viskositas}

Uji viskositas bertujuan untuk mengetahui kekentalan dari suatu sediaan pasta gigi. Viskositas merupakan suatu parameter yang menggambarkan besarnya tahanan suatu cairan untuk mengalir. Semakin besar tahanannya, maka viskositas juga akan semakin besar. Hasil uji viskositas dapat dilihat pada Tabel V.

Tabel V. Viskositas pasta gigi T-EEDS

\begin{tabular}{cc}
\hline Formula & Rata-rata (dPas) \pm SD \\
\hline FI & $340 \pm 26,46$ \\
FII & $330 \pm 17,32$ \\
FIII & $340 \pm 20,00$ \\
K(-) & $316,6 \pm 5,77$ \\
\hline
\end{tabular}

Hasil uji viskositas menunjukkan bahwa tiap formula memiliki viskositas yang tinggi bila dibandingkan dengan kontol basis $\mathrm{K}(-)$, dan sudah memenuhi syarat viskositas pasta gigi yaitu pada kisaran 300 dPas (Mollet and Grubenmann, 2001). Sehingga bisa dimungkinkan ketika sediaan pasta gigi digunakan akan tertahan lama atau tidak mudah meleber pada tube dan sikat gigi.

\section{Daya busa}

Uji daya busa sediaan pasta gigi dapat dilihat pada Tabel VI.

Tabel VI. Daya busa pasta gigi T-EEDS

\begin{tabular}{cc}
\hline Formula & Rata-rata \pm SD \\
\hline F I & $5,80 \pm 1,02$ \\
F II & $5,03 \pm 0,32$ \\
FIII & $5,06 \pm 0,64$ \\
K(-) & $5,60 \pm 1,15$ \\
\hline
\end{tabular}

Hasil uji daya busa menunjukkan bahwa tiap formula memiliki daya busa yang hampir sama, sehingga dimungkinkan tidak adanya pengaruh dari adanya penambahan triklosan dan daun suji pada sediaan. Suatu sediaan pasta gigi dikatakan baik jika terbentuk busa (Aljufri, 2010)

\section{Aktivitas antibakteri sediaan pasta gigi pada Streptococcus mutans}

Aktivitas antibakteri sediaan pasta gigi kombinasi T-EEDS dapat di lihat pada Gambar 1 dan pada Tabel VII. 
Tabel VII. Aktivitas antibakteri sediaan pasta gigi T-EEDS

\begin{tabular}{lccc}
\hline \multirow{2}{*}{ Formula } & \multicolumn{2}{c}{$\begin{array}{c}\text { Rata-rata DDH (mm) } \pm \text { SD } \\
\text { (sebelum dikurangi kontrol basis) }\end{array}$} & $\begin{array}{c}\text { Rata-rata DDH (mm) } \pm \text { SD } \\
\text { (setelah dikurangi kontrol basis) }\end{array}$ \\
\hline & FI & $44,23 \pm 0,50$ & $24,3 \pm 0,50$ \\
& FII & $38,47 \pm 1,57$ & $18,54 \pm 1,57$ \\
& FIII & $22,00 \pm 2,48$ & $2,07 \pm 2,48$ \\
& K(-) & $19,93 \pm 3,02$ & 0 \\
\hline Keterangan & : & \\
FI & : Pasta gigi T-EEDS (1,0:0,0) & \\
FII & : Pasta gigi T-EEDS (0,5:0,5) & \\
FIII & : Pasta gigi T-EEDS (0,0:1,0) & \\
K(-) & : Pasta gigi tanpa T-EEDS
\end{tabular}

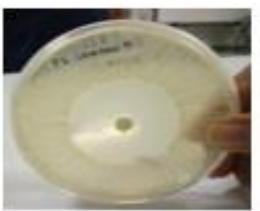

FI 3

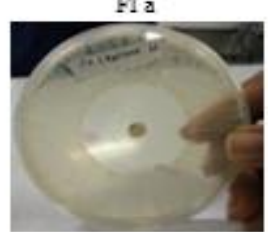

FII

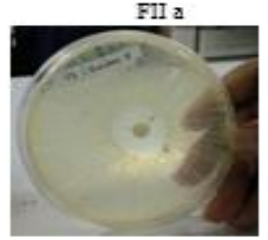

FIII a

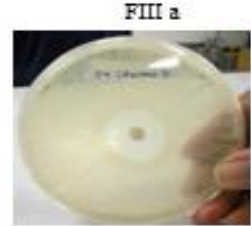

$\mathrm{K}(-) \mathbf{z}$

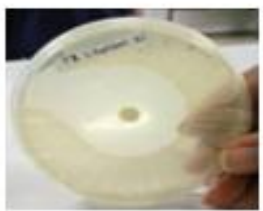

FI b

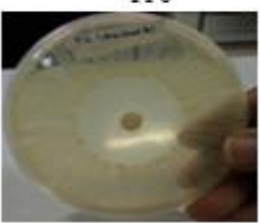

FII b

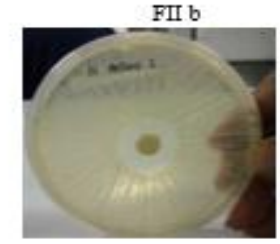

FIII b

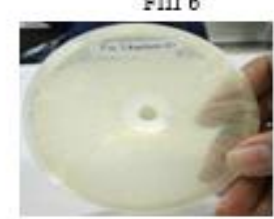

$\mathbf{K}(-) b$

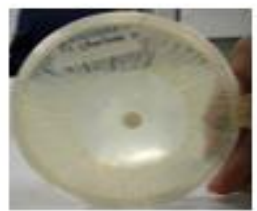

FI

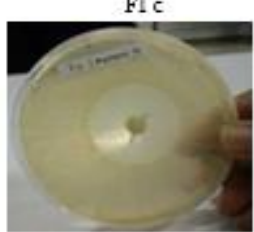

FII c

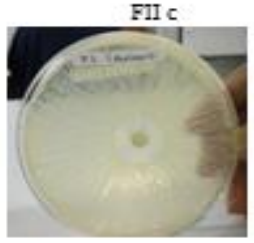

FIII C

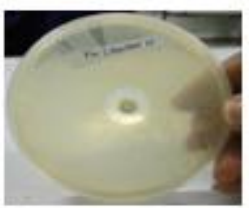

$\mathbf{K}(-)$

Gambar 1. Aktivitas antibakteri sediaan pasta gigi T-EEDS

\section{PEMBAHASAN}

Pengujian kandungan senyawa aktif ini dilakukan untuk mengetahui senyawa kimia yang terkandung dalam ekstrak etanol daun suji. Hasil pengujian fitokimia menunjukkan bahwa ekstrak daun suji positif mengandung senyawa flavonoid, alkaloid, tanin, dan saponin.

Formulasi sediaan pasta gigi T-EEDS dibuat dengan 3 variasi kombinasi triklosan : ekstrak dengan konsentrasi yaitu FI(1:0); FII(0,5:0,5); FIII(0:1) serta formula pasta gigi tanpa ekstrak dibuat sebagai kontrol negatif K(-). Evalusi karakteristik fisika kimia meliputi uji organoleptik, uji homogenitas, uji pH, uji viskositas, dan uji pembentukan busa. Pengujian organoleptik menunjukkan bahwa pada ketiga formula menghasilkan tampilan yang hampir sama yaitu tekstur yang semi padat, putih agak kehijauan, dan bau yang khas daun suji kombinasi mint, serta semua formula pasta gigi homogen. Hal ini menunjukkan bahwa bahan tambahan dan ekstrak yang digunakan dalam sediaan 
pasta gigi pada setiap formula terdispersi merata dan tidak adanya partikel - partikel kasar sehingga menghasilkan sediaan yang homogen.

Pada pengujian viskositas menunjukkan bahwa tiap formula memiliki viskositas yang tinggi dan hampir sama, sehingga dimungkinkan sediaan pasta yang dibuat akan tertahan lama pada tube dan sikat gigi. Dari hasil tersebut dimungkinkan tidak ada pengaruh dari adanya penambahan triklosan dan ekstrak pada formula terhadap viskositasnya. Nilai $\mathrm{pH}$ pasta gigi pada berbagai formula masih masuk dalam persyaratan $\mathrm{pH}$ untuk pasta gigi yaitu berkisar antara 4,5-10,5. Namun bisa dilihat pada formula F2 dan F3 yang diberikan ekstrak memiliki nilai pH yang lebih kecil bila dibandingkan dengan FI yang hanya diberikan triklosan, hal ini dimungkinkan karena pada pasta gigi mengandung ekstrak yang didalmnya terdapat kandungan flavonoid, alkaloid, tannin yang bersifat asam sehingga dimungkinkan dapat menurunkan $\mathrm{pH}$ sediaan. Pada Pengujian pembentukan busa menunjukkan daya busa antar formula hampir sama,

Pengujian aktivitas antibakteri pasta gigi T-EEDS dilakukan untuk mengetahui daya hambat masing-masing formula dengan metode sumuran. Bakteri uji yang digunakan adalah Streptococcus mutans, yang mana bakteri tersebut merupakan salah satu bakteri penyebab kejadian plak pada gigi. Pengujian dengan metode sumuran akan didapatkan data diameter daya hambat (DDH) pada berbagai formula. Data DDH yang diperoleh merupakan selisih antara diameter daya hambat sediaan pasta TEEDS dengan kontrol basis. Secara teoritis, suatu bahan baru dapat dikatakan memiliki aktivitas antibakteri bila diameter hambatan yang terbentuk adalah lebih dari atau sama dengan $6 \mathrm{~mm}$. Selain itu, kriteria kekuatan daya antibakteri dapat dikategorikan lemah jika DDH $5 \mathrm{~mm}$ atau kurang, dikategorikan sedang apabila DDH 5-10 mm, dan dikategorikan kuat apabila DDH 10-20 mm, dan sangat kuat apabila DDH $20 \mathrm{~mm}$ atau lebih (Depkes RI, 1989). Berdasarkan pengujian tersebut didapatkan hasil bahwa FI (pasta gigi berisi triklosan 0,3\%) memiliki DDH paling besar yaitu 24,3 $\mathrm{mm}$, hasil tersebut menunjukkan bahwa triklosan tergolong sebagai senyawa yang memiliki aktivitas antibakteri sangat kuat $(>20 \mathrm{~mm}$ ). Pada formula FII (pasta gigi kombinasi Triklosan:ekstrak dengan perbandingan 0,5:0,5) memiliki aktivitas antibakteri sebesar 18,54 $\mathrm{mm}$, hasil tersebut menunjukkan bahwa kombinasi triklosan dan ekstrak tergolong sebagai senyawa yang memiliki aktivitas antibakteri dengan kekuatan kuat. Sedangkan Pada formula FIII (pasta gigi yang berisi ekstrak 0,3\%) memiliki aktivitas antibakteri sebesar 2,07 mm, hasil tersebut menunjukkan bahwa ektrak daun suji 0,3\% tergolong sebagai senyawa yang memiliki aktivitas antibakteri dengan kekuatan lemah. Dari hasil tersebut menunjukkan bahwa pada formula pasta gigi yang dikombinasi (FII) memiliki nilai DDH yang jauh lebih besar bila dibandingkan dengan formula pasta gigi yang senyawa aktifnya hanya ekstrak (FIII). Hal ini bisa dimungkinkan bahwa ketika triklosan dikombinasikan dengan ekstrak akan menghasilkan efek yang sinergis, sehingga bisa menghasilkan aktivitas antibakteri yang lebih besar bila dibandingkan dengan pasta gigi yang hanya mengandung ekstrak saja. Aktivitas antibakteri pada sediaan yang mengandung ekstrak dimungkinkan berasal dari senyawa aktif yang ada dalam suji yaitu flavonoid, alkaloid, saponin, dan tannin. Mekanisme flavonoid sebagai antibakteri adalah dengan membentuk senyawa kompleks terhadap protein ekstraseluler yang menyebabkan rusaknya susunan dan perubahan mekanisme membran sel bakteri. Mekanisme alkaloid sebagai antibakteri adalah dengan cara mengganggu komponen penyusun peptidoglikan pada sel bakteri, sehingga lapisan dinding sel tidak terbentuk secara utuh dan menyebabkan kematian sel tersebut.. mekanisme tanin diduga sebagai antibakteri adalah dengan cara tannin dapat mengkerutkan dinding sel atau membran sel sehingga mengganggu permeabilitas sel itu sendiri. Akibat terganggunya permeabilitas, sel tidak dapat melakukan aktivitas hidup sehingga pertumbuhannya akan terhambat atau bahkan mati. Mekanisme saponin sebagai aktivitas antibakteri adalah dengan cara menurunkan tegangan permukaan sehingga mengakibatkan naiknya permeabilitas atau kebocoran sel dan mengakibatkan senyawa intraseluler akan keluar (Jawetz et al., 2005). Berdasarkan hasil uji aktivitas antibakteri dapat diperoleh kesimpulan bahwa formula pasta gigi kombinasi (FII) bisa digunakan sebagai alternatif pengganti sediaan pasta gigi yang ada dipasaran dengan bahan aktif triklosan sehingga dapat meminimalkan efek yang tidak diharapkan dari triklosan dalam sediaan pasta gigi, triklosan bersifat 
korosif, resisten terhadap bakteri, dan mempengaruhi sistem hormonal khusunya hormon tiroid (FDA, 2016).

\section{KESIMPULAN}

Berdasarkan hasil penelitian dapat disimpulkan bahwa pengujian karakteristik fisika kimia semua formula memenuhi karakteristik fisik kimia pasta gigi. Pasta gigi T-EEDS (0,5:0,5) (FII) memiliki aktivitas antibakteri yang kuat terhadap Streptococcus mutans sehingga bisa digunakan sebagai alternatif pengganti sediaan yang sudah ada di pasaran dengan zat aktif triklosan.

\section{UCAPAN TERIMAKASIH}

Ucapan terima kasih saya sampaikan kepada Menristekdikti yang sudah memberikan dana pada penelitian dosen pemula ini. Terima kasih saya sampaikan kepada Alm. Bp. Sugiyono M. Sc., Apt beserta tim suji (Rima, Eko, Azam, Selma, Prita) yang sudah banyak membantu dalam proses penelitian ini.

\section{DAFTAR PUSTAKA}

Aljufri, A.H, 2010, Pengaruh Variasi Konsentrasi CMC Na Sebagai Bahan Pengikat Terhadap Sifat Fisik dan Daya Hambat Bakteri Streptococcus mutans Sediaan Pasta Gigi Ekstrak The Hitam (Camelia Sinesis), Skripsi, Universitas Muhammadiyah Surakarta.

Andarini, D., 2012, Uji Aktivitas Antibakteri Daun Suji (Pleomele angustifolia N.E Brown)Terhadap Staphylococcus Aureus dan Shigella Sp, Skripsi, Fakultas Farmasi Universitas Pancasila, Jakarta.

Anitasari, S., dan Rahayu, N.E., 2005, Hubungan Frekuensi Menyikat Gigi Dengan Tingkat Kebersihan Gigi dan Mulut Siswa Sekolah Dasar Negeri di Kecamatan Palaran Kotamadya Samarinda Provinsi Kalimantan Timur, Maj. Ked. Gigi. (Dent. J.), 38(2): 88-90.

Depkes RI, 1989, Materia Medika Indonesia. Jilid V, Jakarta, Direktorat Jendral Pengawasan Obat dan Makanan, 194.

Faridah., Natalia., Maria Lina, and Hendig W, 2014, Isolation, Identification, and Antibacterial Activity of Chemical Compounds from Ethanolic Extract of suji leaf (Pleomole Angustifolia N.E Brown), $4^{\text {th }}$ International Conference and Mathematics and Natural Sciences (ICMNS 2012), AIP conf. Proc, 1589: 431-435.

FDA, 2016, 5 Things to Know About Triclosan, diakses tanggal 20 Agustus 2017, dari https://www.fda.gov/ForConsumers/ConsumerUpdates/ucm205999.htm\#2.

Jawetz, E. J., Melnick, L., Adelberg, E. A., 2005, Microbiologi Untuk Profesi Kesehatan, Terjemahan Huriati dan Hartanto, Penerbit Buku Kedokteran EGC, Surakarta.

Jokopriyambodo, W., Sudarsono, and Rohman, Abdul, 2014, The Antiradical Activity of Insoluble Water Suji (Pleomele angustifolia N.E. Brown) Leaf Extract and Its Application as Natural Colorant in Bread product, J.Food Pharm.Sci, 2 (2): 52-56.

Lay,W.B, 1994, Analisa Mikroba di Laboratorium. Edisi I, Jakarta, PT.Raja Grafindo Persada, 145

Mitsui, T., 1998, New Cosmetic Science, Elsevier Science, Amsterdam, Netherlands, 479.

Mollet, H., and Grubenmann, A., 2001, Formulation Technology, translated by H.R. Payne, WilyehVch, Germany, 256.

Pragdimurti, E., Muchtadi, D., Astawan, M., Zakaria, F.R, 2006, Aktivitas Antioksidan Ekstrak Daun Suji (Pleomole Angustifolia N.E Brown), Jurnal Teknol dan Industri Pangan, 17(2):79-86.

Putri, W.D.R., Zubaidah, E., and Sholahudin, N, 2012, Ekstraksi Pewarna Alami Daun Suji, Kajian Pengaruh Blanching dan Jenis Bahan Pengekstrak, J. Tek. Pert, 4 (1):13 - 24. 
